DOI: https://doi.org/10.15688/lc.jvolsu.2020.3.21

UDC 340.12(470+571)

Submitted: 05.09.2020

LBC 67.1(2)6-8

Accepted: 15.09 .2020

\title{
FOR THE ANNIVERSARY OF PROFESSOR V.M. BARANOV
}

\author{
Marina L. Davydova \\ Volgograd State University, Volgograd, Russian Federation
}

\begin{abstract}
Citation. Davydova M.L. For the Anniversary of Professor V.M. Baranov. Legal Concept, 2020, vol. 19, no. 3 , pp. 144-148. (in Russian). DOI: https://doi.org/10.15688/lc.jvolsu.2020.3.21

УДК $340.12(470+571)$

Дата поступления статьи: 05.09.2020

ББК 67.1(2)6-8

Дата принятия статьи: 15.09.2020
\end{abstract}

\section{К ЮБИЛЕЮ ПРОФЕССОРА В.М. БАРАНОВА}

\author{
Марина Леонидовна Давыдова \\ Волгоградский государственный университет, г. Волгоград, Российская Федерация
}

\begin{abstract}
Цитирование. Давыдова М. Л. К юбилею профессора В.М. Баранова // Legal Concept = Правовая парадигма. -2020. - Т. 19, № 3. - C. 144-148. - DOI: https://doi.org/10.15688/lc.jvolsu.2020.3.21
\end{abstract}

6 августа 2020 г. свой 75-летний юбилей отмечает доктор юридических наук, професcop, заслуженный деятель науки Российской Федерации, почетный работник высшего профессионального образования Российской Федерации Владимир Михайлович Баранов.

Жанр юбилейной статьи требует изложения формальных этапов профессиональной биографии. Вот они:

1964-1967 гг. - служба в армии.

1968-1972 гг. - студент дневного отделения Саратовского юридического института им. Д.И. Курского (сейчас Саратовская государственная юридическая академия).

1975-1981 гг. - преподаватель, старший преподаватель, доцент кафедры теории госуㄱ дарства и права Саратовского юридического ॄิ института.

С 1981 г. - Нижегородская академия МВД России: доцент, затем начальник кафедры государственно-правовых дисциплин, с 2000 по 2007 г. - заместитель начальника академии по научной работе. Ныне помощник (?) начальника академии по инновационному раз- витию научной деятельности, полковник милиции в отставке.

В 1991 г. В.М. Баранову присвоено ученое звание профессора. В 1996 г.он избран действительным членом Петровской академии науки и искусств, в том же году - действительным членом Российской академии естественных наук; в 2004 г. - действительным членом Российской академии юридических наук. В 2008 г. - почетный профессор Нижегородской академии МВД России.

В перечне многообразной общественной деятельности В.М. Баранова в разные годы фигурируют членство в экспертной группе Комиссии по вопросам привилегий и льгот Верховного Совета СССР, работа экспертом Правового управления Аппарата Государственной Думы Федерального Собрания Российской Федерации, руководство согласительной комиссией по приведению в соответствие нормативно-правовых актов республик Татарстан и Башкортостан с федеральным законодательством, руководство Научно-гуманитарным советом МВД России, членство в Экс- 
пертном совете ВАК Минобрнауки по праву, в Междисциплинарном совете по координации научного и учебно-методического обеспечения противодействия коррупции, в Экспертном совете при Уполномоченном по правам человека в Российской Федерации, в научно-консультативном совете при Законодательном собрании Нижегородской области (заместитель председателя).

Впечатляет и список наград, среди которых орден Почета, медаль ордена «За заслуги перед Отечеством» II степени, медали «За безупречную службу» I, II и III степеней, нагрудный знак «Почетный сотрудник МВД Российской Федерации», медали «За доблесть в службе», «За трудовую доблесть», «Ветеран труда», медаль Анатолия Кони, бесчисленные грамоты, благодарности и премии от федеральных и региональных органов власти, общественных и профессиональных объединений.

Научная биография В.М. Баранова в первую очередь связана с двумя темами его исследований в области теории права: поощрительными правовыми нормами (1975 г. - защита кандидатской диссертации «Поощрительные нормы советского права») и истинностью правовых норм (1990 г. - защита докторской диссертации «Истинность норм советского права (проблемы теории и практики)»).

Сам выбор исследовательской проблематики свидетельствует о стремлении автора к оригинальному, самостоятельному подходу в научных изысканиях.

В первом случае это желание связать право не с наказанием, а с поощрением, развернутое обоснование роли поощрения как стимулятора социальной активности субъектов права; способа согласования личных, общественных и государственных интересов; фактора мотивации правомерного поведения. В то время как абсолютное большинство исследователей развивают ленинскую мысль о том, что право - ничто без аппарата принуждения, В.М. Баранов с формально-юридических и морально-психологических позиций раскрывает особенности структуры поощрительных норм права и специфику правоотношений, возникающих на их основе, обосновывает предложения по систематизации поощрительных норм права [6].
Еще более оригинальной и в какой-то степени безрассудной была постановка вопроса об истинности норм советского права. Вопервых, подспудно эта формулировка допускала сомнение в безупречности советского права: ведь если ставится задача оценить, насколько истинными являются действующие нормы, то неминуемо некоторые из них окажутся ложными. Во-вторых, сама идея использования критерия истинности применительно к нормам права до сих пор имеет серьезных противников в науке. Выбрать для докторской диссертации, успех которой напрямую зависит от ее благосклонного восприятия научным сообществом, такую спорную тему было решением очень смелым, требующим большой уверенности в победе.

В работе В.М. Баранов обосновывает необходимость истинностной оценки юридических норм, исследует логико-гносеологическую и юридико-социологическую природу истинности, ее взаимосвязь с социальной ценностью, эффективностью, динамизмом и справедливостью правовых норм. Автор обрисовывает нормы права как процесс и результат отражения человеческой деятельности, раскрывает информационно-познавательный характер их содержания. По его убеждению, истинность - объективное свойство нормы права, выражающее проверяемую практикой меру пригодности ее содержания и формы в виде познавательно-оценочного образа соответственно отражать тип, вид, уровень либо элемент развития прогрессивной человеческой деятельности. В.М. Баранов раскрывает сущность и причины проявления в праве ложных норм, предлагает пути их ликвидации как фактора торможения общественного и государственного развития, обосновывает роль правовой практики как критерия истинности государственных установлений [3].

Дискуссия об истинности правовых норм идет до сих пор, и Владимир Михайлович продолжает горячо отстаивать свои идеи, доказывая, что противники истинностной характеристики юридических норм упускают из виду многозначность истины. Сводить истину к характеристике знания, полагает В.М. Баранов, значит видеть лишь одно ее измерение. Истина присутствует в познании множеством форм, проявляя тем самым многомерность как 


\section{ХРОНИКА НАУЧНОЙ ЖИЗНИ}

сущностную характеристику. Исследователь утверждает, что для практического освоения идей истинности норм права еще не пришло время и связывает ее будущее с дальнейшей разработкой регулятивной функции истины.

Не оставил он и тему поощрения в праве, в разные годы обращаясь к тем или иным ее аспектам. В частности, серьезную разработку на монографическом уровне получило понятие «депоощрение» [9].

Есть целый ряд других проблем, которые Владимир Михайлович исследует в своих публикациях: система и систематизация законодательства, теневое право, рекламное законодательство, экстерриториальное пространство права, критика законодательства, теория и практика юридических рекомендаций. Им опубликовано около 550 научных и научно-методических работ общим объемом в полторы тысячи печатных листов.

Но чаще всего в течение последних 20 лет имя профессора В.М. Баранова связывают с научным направлением, в развитие которого он внес неоценимый вклад, - с юридической техникой. Речь идет не только о собственных исследовательских работах Владимира Михайловича, посвященных концепции нормативно-правового акта [4], преамбулам в праве [7], критике законодательства [8], не только о многократно переиздаваемом ретроспективном библиографическом указателе по юридической и правотворческой технике, но и о роли Владимира Михайловича как организатора научных мероприятий и инициатора коллективных исследовательских проектов.

Начиная с 1999 г. в Нижнем Новгороде регулярно проводятся масштабные конференции по юридической технике, ставшие катализатором развития данного научного направления в современной отечественной юриспруденции. В 2006 г. В.М. Баранов создает Нижегородский исследовательский научноприкладной центр «Юридическая техника», становится его президентом. С 2007 г. начинается выпуск ежегодника «Юридическая техника». На конференциях и в изданных по их итогам объемных материалах за прошедшие годы были рассмотрены как общие методологические и теоретические проблемы юридической техники, так и более конкретные вопросы, касающиеся отдельных видов юри- дической техники (законотворческая и правотворческая техника, техника кодификации, техника конкретизации права), различных технико-юридических средств и приемов (законодательная дефиниция, юридическая конструкция, правовая презумпция, юридическая аргументация, принципы законодательства, правовые ограничения), социальных явлений, значимых для понимания закономерностей развития современной юридической техники (преемственность в праве, демократизация правотворчества, правовые риски, правотворческие ошибки, юридические коллизии).

Важным итогом этой работы стало продвижение идеи о необходимости преподавания юридической техники в системе вузовской подготовки правоведов. Определенную роль в популяризации данной учебной дисциплины сыграли и проведенная в 2008 г. тематическая конференция, и переживший многократные переиздания коллективный учебник по юридической технике под редакцией В.М. Баранова, и инициируемые им дискуссии по конкретным вопросам профессионального юридического образования [10]. Но главное, благодаря 20-летней активной работе научной площадки под руководством В.М. Баранова, само понятие «юридическая техника» из разряда периферийных, второстепенных категорий общей теории права перешло в статус самостоятельного междисциплинарного направления исследований, объединяющего десятки специалистов из России и ближнего зарубежья.

Для множества ученых Владимир Михайлович является научным отцом. Это и почти сотня подготовленных им докторантов и адъюнктов (под руководством В.М. Баранова защищено 10 докторских и 87 кандидатских диссертаций) и огромное количество диссертантов, защитившихся в диссертационном совете Нижегородской академии МВД России, который он возглавляет на протяжении почти 30 лет, и те, чья известность в науке в значительной мере связана с участием в конференциях и изданиях, инициированных В.М. Барановым. Именно в этом широком смысле можно говорить о научной школе профессора В.М. Баранова, объединяющей множество теоретиков и отраслевиков, проводящих исследования в области юридической техники [5]. 
Помимо издания монографий и научных сборников, профессор В.М. Баранов выполняет обязанности главного редактора журнала «Юридическая наука и практика: Вестник Нижегородской академии МВД России», возглавляет редколлегию ежегодника «Юридическая техника». Он член редакционных коллегий журналов «Актуальные проблемы правоведения» (Самара), «Философия права» (Ростов-на-Дону), «Юридическая мысль» (Волгоград), «Вестник Уфимского юридического института МВД России», «Вестник Саратовской государственной юридической академии», «Юридическая наука и правоохранительная практика» (Тюмень), «Вектор науки Тольяттинского государственного университета. Серия: Юридические науки» (Тольятти), «Вопросы российского и международного права», «Юридическое образование и наука» (Москва), «Вестник Владимирского юридического института» (Владимир).

Круг его интересов не ограничивается сугубо научными проблемами. Юриспруденция предстает в его понимании как целая жизнь со своими радостями и горестями. По инициативе и при участии В.М. Баранова изданы и систематически переиздаются две, казалось бы, полярные по жанру, но объединенные глубоким уважением к юридической деятельности книги - «Антология юридического некролога» [2] и «Антология юридического анекдота» [1]. Владимир Михайлович коллекционирует дореволюционную юридическую литературу, но и к новейшим изданиям проявляет живой интерес, стремясь быть в курсе всего, что происходит в юридической науке. Каждая вышедшая монография по интересующей его проблематике (а это бесконечное множество вопросов юридической науки) непременно должна оказаться в личной библиотеке В.М. Баранова.

Владимир Михайлович родился в августе 1945 г., через три месяца после Победы. Возможно, поэтому иногда кажется, что во всех делах ему сопутствует уверенная радость победителя. Все, что он делает, это ярко и масштабно. Во всем виден его неповторимый стиль. Если конференция, то обязательно международный форум, если сборник статей, то не меньше 1000 страниц. Все его друзья великие и знаменитые, и даже те, кто пока далек от мировой славы, чувствуют себя больше и значительнее от того, что попадают под его обаяние.

Хочется пожелать Владимиру Михайловичу новых масштабных проектов, ярких научный идей, достойных учеников, благополучия близких и личного счастья!

\section{СПИСОК ЛИТЕРАТУРЫ}

1. Антология юридического анекдота / сост. В. М. Баранов. - М. : Проспект, 2019. - 911 с.

2. Антология юридического некролога / сост. В. М. Баранов. - М. : Городец, 2019. - 1294 с.

3. Баранов, В. М. Истинность норм советского права (проблемы теории и практики) / В. М. Баранов. - Саратов : СГУ, 1989.- 400 с.

4. Баранов, В. М. Концепция законопроекта / В. М. Баранов. - Н. Новгород : НА МВД РФ, 2003.$190 \mathrm{c}$.

5. Баранов, В. М. Опыт формирования и функционирования научной школы техники правотворчества / В. М. Баранов. - М. : Проспект, 2019. - 496 с.

6. Баранов, В. М. Поощрительные нормы советского социалистического права / В. М. Баранов. Саратов : СГУ, 1978. - $146 \mathrm{c}$.

7. Баранов, В. М. Преамбула нормативного правового акта (доктрина, практика, техника) / В. М. Баранов. - М. : Юрлитинформ, 2014. $248 \mathrm{c}$.

8. Баранов, В. М. Критика законодательства (теория, практика, техника) / В. М. Баранов, П. В. Ремизов. - М. : Проспект, 2018. - 352 с.

9. Депоощрение по российскому праву (доктрина, практика, техника) / В. М. Баранов [и др.]. М. : ИНФРА-М, 2017. -448 c.

10. Норморайтер как профессия : материалы дискуссии. - Н. Новгород : РГ-Пресс, 2019. - 376 с.

\section{REFERENCES}

1. Baranov V.M. Antologiya yuridicheskogo anekdota [Anthology of Legal Anecdote]. Moscow, Prospekt Publ., 2019. 911 p.

2. Baranov V.M. Antologiya yuridicheskogo nekrologa [Legal Obituary Anthology]. Moscow, Gorodets Publ., 2019. 1294 p.

3. Baranov V.M. Istinnost norm sovetskogo prava (problemy teorii i praktiki) [The Truth of the Norms of Soviet Law (Problems of Theory and Practice)]. Saratov, SGU, 1989.400 p.

4. Baranov V.M. Kontseptsiya zakonoproekta [Bill Concept]. Nizhniy Novgorod, NA MVD RF, 2003. $190 \mathrm{p}$. 


\section{ХРОНИКА НАУЧНОЙ ЖИЗНИ}

5. Baranov V.M. Opyt formirovaniya $i$ funktsionirovaniya nauchnoy shkoly tekhniki pravotvorchestva [The Experience of the Formation and Functioning of the Scientific School of Lawmaking Techniques]. Moscow, Prospekt Publ., 2019. 496 p.

6. Baranov V.M. Pooshchritelnye normy sovetskogo sotsialisticheskogo prava [Incentive Norms of Soviet Socialist Law]. Saratov, SGU, 1978. 146 p.

7. Baranov V.M. Preambula normativnogo pravovogo akta (doktrina, praktika, tekhnika) [Preamble of a Regulatory Legal Act (Doctrine, Practice, Technique)]. Moscow, Yurlitinform, 2014. 248 p.
8. Baranov V.M., Remizov P.V. Kritika zakonodatelstva (teoriya, praktika, tekhnika) [Criticism of legislation (Theory, Practice, Technique)]. Moscow, Prospekt Publ., 2018. 352 p.

9. Baranov V.M., ChernyavkijA.G., Devyashin I.V., Peshekhonov D.A. Depooshchrenie po rossiyskomu pravu (doktrina, praktika, tekhnika) [De-promotion Under Russian Law (Doctrine, Practice, Technique)]. Moscow, INFRA-M Publ., 2017. 448 p.

10. Normorayter kak professiya: materialy diskussii [Normwriter as a Profession. Discussion Materials]. Nizhniy Novgorod, RG-Press Publ., 2019. $376 \mathrm{p}$.

\section{Information About the Author}

Marina L. Davydova, Doctor of Sciences (Jurisprudence), Professor, Head of the Department of Constitutional and Municipal Law, Volgograd State University, Prosp. Universitetsky, 100, 400062 Volgograd, Russian Federation, davidovavlg@gmail.com, davidovaml@volsu.ru, https://orcid.org/0000-0001-8392-9592

\section{Информация об авторе}

Марина Леонидовна Давыдова, доктор юридических наук, профессор, заведующий кафедрой конституционного и муниципального права, Волгоградский государственный университет, просп. Университетский, 100, 400062 г. Волгоград, Российская Федерация, davidovavlg@gmail.com, davidovaml@volsu.ru, https://orcid.org/0000-0001-8392-9592 